\title{
Insecticidal Effects of the Annonaceous Acetogenin Squamocin and the Acetogenin Fraction of Seeds of Rollinia occidentalis on Soybean and Corn Pests
}

\author{
Diego Tolosaํ, José Ruiz Hidalgo', Pedro Eugenio Sal1, Susana Popich², Alicia Bardón1,3, \\ Adriana Neske ${ }^{*}$ \\ ${ }^{1}$ Instituto de Química Orgánica, Facultad de Bioquímica, Química y Farmacia, Universidad Nacional de Tucumán, \\ Ayacucho, Argentina \\ ${ }^{2}$ Universidad Nacional de Chilecito, Chilecito, Argentina \\ ${ }^{3}$ INQUINOA-CONICET, Tucumán, Argentina \\ Email: ${ }^{*}$ aneske@fbqf.unt.edu.ar
}

Received 15 September 2014; revised 18 October 2014; accepted 5 November 2014

Copyright $@ 2014$ by authors and Scientific Research Publishing Inc.

This work is licensed under the Creative Commons Attribution International License (CC BY).

http://creativecommons.org/licenses/by/4.0/

(c) (i) Open Access

\begin{abstract}
A treatment based on the acetogenin fraction of the methanol extract of Rollinia occidentalis seeds was applied to soybean crops for three consecutive years. In relation to the control population, the treatment reduced the population of Anticarsia gemmatalis, Rachiplusia nu, Pseudoplusia includens, Loxostege bifidalis and Spodoptera frugiperda to $52 \%$ and $65 \%$ after $48 \mathrm{~h}$ of application at concentrations of 500 and $750 \mu \mathrm{g} / \mathrm{mL}$ respectively, while low toxic effects were detected on natural enemies. The extract treatment at $500 \mu \mathrm{g} / \mathrm{mL}$ and a solution of the annonaceous acetogenin, squamocin, at 50 and $100 \mu \mathrm{g} / \mathrm{mL}$, were also applied to a corn field to produce $75 \%, 93 \%$ and $100 \%$ mortality rates on the population of $S$. frugiperda, respectively, after $72 \mathrm{~h}$ of application. In addition, damages caused by lepidopterans in treated crops were lower than those observed in non treated fields, evaluated by residual biomass. This statement is based on data from trials with the commercially available insecticides lufenuron and cypermethrin.
\end{abstract}

\section{Keywords}

Annonaceous Acetogenins, Polyphagous Lepidopteran, Soybean Crops, Corn Crops, Spodoptera frugiperda

\footnotetext{
${ }^{*}$ Corresponding author.
}

How to cite this paper: Tolosa, D., Hidalgo, J.R., Sal, P.E., Popich, S., Bardón, A. and Neske, A. (2014) Insecticidal Effects of the Annonaceous Acetogenin Squamocin and the Acetogenin Fraction of Seeds of Rollinia occidentalis on Soybean and Corn Pests. Journal of Agricultural Chemistry and Environment, 3, 156-160. http://dx.doi.org/10.4236/jacen.2014.34019 


\section{Introduction}

Insecticidal and toxic effects of annonaceous acetogenins (ACG) isolated from several Annonaceae family members, have been reported on several insect species [1]-[8]. Natural products with insecticidal activity are an interesting alternative for pest control because they biodegrade rapidly and are beneficial for both man and environment.

Spodoptera frugiperda (J.E. Smith) is a polyphagous lepidopteran commonly called fall armyworm, a major pest in corn fields where it feeds on leaves, tassels and ears of corn [9]-[11]. It has become one of the most serious problems for corn crops in tropical and subtropical regions of Latin America for the important damages it produces. S. frugiperda displays a very wide host range with over 80 plants recorded, though grasses are preferred. Severe damages are particularly caused during its last two larval stages [12]-[15].

A previous publication, informed that the methanol extract of Rollinia occidentalis R.E. Fr. seeds collected in Tucumán (Argentina), incorporated to the larval diet at 100 and $250 \mu \mathrm{g} / \mathrm{g}$ displayed toxic effects on S. frugiper$d a$. On the other hand, five pure acetogenins isolated from the mentioned plant collection, sylvaticin, rolliniastatin-1, rolliniastatin-2, motrilin and desacetyluvaricin, produced nutritional alterations and mortality close to $90 \%$ on early larval instars of $S$. frugiperda at 50 and $100 \mu g$ per g of diet [16].

New control methods are necessary for crop pest management programs due to the widespread problems of insecticide-resistant populations and the increasing consumer concern regarding pesticide residues in food products. Thus, this study evaluated the bioactivity of the annonaceous acetogenin, squamocin, isolated from Annona cherimolia (Annonaceae) [17], and the acetogenin fraction of the methanol extract of R. occidentalis seeds against $S$. frugiperda, which is a primary insect pest of corn.

Particularly the seeds, are a promising source of ACG that can be used as a prototype model and/or a biorational insecticide for the control of S. frugiperda. The commercial insecticides lufenuron (LUF) and cypermetrin (CYP) at $250 \mu \mathrm{g} / \mathrm{mL}$ were used as positive controls. This is the first report on the treatments mentioned on soybean and corn pests in a field assay.

\section{Experimental}

Plant material: $R$. occidentalis fruits were collected in Tucumán, Argentina, in March 2005. A voucher sample (No. 604639) was deposited at the Herbarium of Instituto Lillo of Tucumán.

A. cherimolia fruits were collected in January 2008, in Tucumán, Argentina. A voucher specimen (LIL 515092) was deposited at the Herbarium of Instituto Lillo of Tucumán.

Acetogenin extraction and purification: The dried and powdered seeds of $A$. cherimolia and $R$. occidentalis were macerated with methanol. The methanolic extracts were evaporated and the residue partitioned in a mixture of $\mathrm{CHCl}_{3} / \mathrm{H}_{2} \mathrm{O}(1: 1)$. The subextracts in chloroform and $\mathrm{H}_{2} \mathrm{O}$ were obtained by vacuum evaporation. The chloroformic subextract was partitioned with a mixture of hexane/methanol (1:1). Squamocin was isolated from A. cherimolia methanolic subextract after treatment with semipreparative RP-HPLC with $\mathrm{MeOH} / \mathrm{H}_{2} \mathrm{O}(80: 20)$. The characterization was assessed by spectroscopic techniques (IR, ${ }^{1} \mathrm{H}-\mathrm{NMR},{ }^{13} \mathrm{C}-\mathrm{NMR}$, and MS) as well as $\alpha_{\mathrm{D}}$ determination, in comparison with previously reported data [5]. Acetogenins represent around $0.07 \%$ of the seed weight. The acetogenin fraction of the $R$. occidentalis methanol seed extract was selected for the present study.

\subsection{Treatment Formulations}

Test solution. The acetogenin fractions of the $R$. occidentalis methanol seed extract were prepared at 42.5 , 125, 250, 500 and $750 \mu \mathrm{g} / \mathrm{mL}$ with destilled water and polysorbate 80 as nonionic surfactant. The pure acetogenin solutions were prepared at 50 and $100 \mu \mathrm{g} / \mathrm{mL}$ under the same conditions.

Test products. Lufenuron and Cypermethrin were applied in this study. The first one is a registered trademark of Syngenta Agro S.A. The formulation in Cypermethrin, the active ingredient of several commercial products available in the crop protection market, is produced by Chemotecnica, Buenos Aires, Argentina. Both test solutions contained $250 \mu \mathrm{g} / \mathrm{mL}$ of destilled water. These solutions served as toxic reference treatments and destilled water served as benign control treatment.

Test plants. Ten Zea mays L. seeds were individually placed in their seed-holes. After germination, seedlings were removed and carried to separate test cages. The pots were then connected to a drip irrigation system, ensuring a regular water supply. During their development the plants were not treated with protection products. 
Field assay. It was conducted in a 0.5 ha experimental plot divided into 12 microplots of $10.0 \times 2.5 \mathrm{~m}$, leaving a $5.0 \mathrm{~m}$ bordure on each side. We evaluated the insecticidal effect of $R$. occidentalis methanol seed extract at five different doses $(42.5,125,250,500$ and $750 \mu \mathrm{g} / \mathrm{mL})$. We compared the performance of insecticidal effects of the extract with two commonly used insecticides in soybean pest control: LUF and CYP and left an untreated patch as control. Each treatment had 3 replicates grouped in a randomized block design in two rows with their respective controls. The plots were hand sprayed with the products from a 20 liter portable pack. The number of arthropods found on a $1 \mathrm{~m}$ long strip of cloth extended between rows after severe shaking was recorded. Each plot was swept 30 times. This treatment was repeated before and after $48 \mathrm{~h}$ of the applications. The treatment was applied to soybean crops for three consecutive years.

Semi-field assay. A semi-field approach was devised to test ACG effects against S. frugiperda second instar larvae that were individually enclosed in 10 seedlings placed in $0.25 \mathrm{~m}^{2}$ meshed cages completely isolated from any other insects. The assays were performed in triplicate for each dose of all products tested. After $24 \mathrm{~h}$, each cage was sprayed with ACG at 50 and $100 \mu \mathrm{g} / \mathrm{mL}$, respectively, as well as with the commercial insecticide, LUF at $250 \mu \mathrm{g} / \mathrm{mL}$. Mortality was evaluated in each cage at 24, 48 and $72 \mathrm{~h}$ after fumigation.

After 10 days each seedling was cut and wrapped in labelled papers in a stove at $50^{\circ} \mathrm{C}$ for $48 \mathrm{~h}$. The damage caused by $S$. frugiperda feeding was estimated by determining the percentage of leaves that were damaged or punctured in each sample through the visual evaluation of each plant. Subsequently, leaf weight loss (\%) was estimated based on the residual biomass (g).

\subsection{Statistical Analysis}

Results are reported as Mean \pm SD. Differences in the mean values were evaluated by analysis of variance (ANOVA). The Tukey test was used for all pair wise multiple comparisons of groups. In all statistical analysis P values $>0.05$ were considered not significant.

\section{Results}

Toxicity of R. occidentalis methanol seed extract on soybean pests in field assays: The results obtained from the three field assays on soybean, showed that treatment with the $R$. occidentalis extract at 500 y $750 \mu \mathrm{g} / \mathrm{mL}$ reduced Lepidoptera population $52 \%$ and $65 \%$ respectively after $48 \mathrm{~h}$ of application when compared with the control population. The treatment with LUF and CYP decreased Lepidoptera population $61 \%$ and $63 \%$, respectively (Table 1).

The extracts displayed low toxic effects on natural enemy populations (spiders, Coleoptera, Pentatomidae and beetles). The results in all plots sprayed with the extract were similar to those treated with the commercially available insecticides (50\%), while pest population control was 100\%. The phytophagous lepidopterans Anticarsia gemmatalis, Rachiplusia nu, Pseduplusia includens, Loxostege bifidalis, Spodoptera frugiperda and S. cosmioides were found in the field, as well as the natural predators, Nabis capsiformis (Nabiidae) and Podisus connexivus (Pentatomidae), commonly present in soybean crops. The results obtained with the toxic referent products LUF and CYP (at 125 and 70 g a.i./l, respectively) showed that larval mortality was high enough to be statiscally significant.

Toxicity of R. occidentalis methanol seed extract and squamocin on S. frugiperda in corn Semi-field assay: We describe a semi-field cage test specifically designed to test effects of plant protection products on $S$. frugiperda. We evaluated the insecticidal activity of $R$. occidentalis methanol seed extract (acetogenin fraction) and bis-THF ACG, squamocin on $S$. frugiperda. Also, we studied the damage caused by the lepidopteran in treated and control crops, quantifying the residual biomass (g).

The acetogenin fraction of $R$. occidentalis methanol seed extract $(500 \mu \mathrm{g} / \mathrm{mL})$ and squamocin (50 and 100 $\mu \mathrm{g} / \mathrm{mL}$ ) produced a mortality of $75 \%, 93 \%$ and $100 \%$ in the population of $S$. frugiperda after $72 \mathrm{~h}$ of treatment while LUF produced a 100\% mortality (Table 2). Note the importance of natural products that exert their toxicity in early instar larvae, when so much damage has not been produced yet.

The damage caused by lepidopterans in treated and control crops was quantified by evaluating the residual biomass after treatment with $R$. occidentalis $(500 \mathrm{mg} / \mathrm{ml}$ ), squamocin (50 y $100 \mathrm{mg} / \mathrm{ml}$ ) and LUF as positive control $(250 \mathrm{mg} / \mathrm{ml})$. The results were $0.42,0.46,0.60$ and $0.80 \mathrm{~g}$, respectively and $0.22 \mathrm{~g}$ for the control (Table 2).

The test proved to be useful to evaluate the effects of the plant protection products sprayed on the crops. 
Table 1. Percentage of arthropod populations after $48 \mathrm{~h}$ of application.

\begin{tabular}{ccccc}
\hline Compounds & Conc. $\mu \mathrm{g} / \mathrm{mL}$ & $1^{\text {st }}$ Field test $^{\mathrm{a}} 48 \mathrm{~h}$ & $2^{\text {nd }}$ Field test $^{\mathrm{a}} 48 \mathrm{~h}$ & $3^{\text {rd }}$ Field test $^{\mathrm{a}} 48 \mathrm{~h}$ \\
\hline Ex. R.o. & 42.5 & $83.0 \pm 1.3$ & $\mathrm{ND}$ & $\mathrm{ND}$ \\
Ex. R.o. & 125 & $68.0 \pm 2.3$ & $59.0 \pm 1.4$ & $\mathrm{ND}$ \\
Ex. R.o. & 250 & $56.1 \pm 2.9$ & $46.1 \pm 3.7$ & $57.1 \pm 3.8$ \\
Ex. R.o. & 500 & $\mathrm{ND}$ & $40.7 \pm 3.5$ & $48.0 \pm 3.3$ \\
Ex. R.o. & 750 & $\mathrm{ND}$ & $\mathrm{ND}$ & $35.0 \pm 3.5$ \\
LUF & 250 & $50.1 \pm 4.6$ & $40.5 \pm 2.1$ & $39.0 \pm 3.1$ \\
CYP & 250 & $45.0 \pm 4.9$ & $33.0 \pm 2.3$ & $37.0 \pm 3.5$ \\
\hline
\end{tabular}

a(\%) arthropod population after $48 \mathrm{~h}$ with respect to control. ND: Not determined.

Table 2. Larval mortality of $S$. frugiperda and residual biomass in a semi-field approach (10 seedlings).

\begin{tabular}{cccccc}
\hline & Control & $\begin{array}{c}\text { Extract R.o. } \\
(500 \mu \mathrm{g} / \mathrm{mL})\end{array}$ & $\begin{array}{c}\text { Squamocin } \\
(50 \mu \mathrm{g} / \mathrm{mL})\end{array}$ & $\begin{array}{c}\text { Squamocin } \\
(100 \mu \mathrm{g} / \mathrm{mL})\end{array}$ & $\begin{array}{c}\text { LUF } \\
(250 \mu \mathrm{g} / \mathrm{mL})\end{array}$ \\
\hline Larval mortality (\%) & 20 & 75 & 93 & 100 & 100 \\
Residual biomass (g) & $0.22 \pm 0.01$ & $0.42 \pm 0.01$ & $0.46 \pm 0.12$ & $0.60 \pm 0.10$ & $0.80 \pm 0.13$ \\
\hline
\end{tabular}

The idea of the trial was to prepare groups of test plants to evaluate the action of different products $24 \mathrm{~h}$ after placing the larvae. A group remained untreated for control. The relatively small size of the test units and the high degree of standardization achieved with the set-up made the test highly reproducible in a test design with various replicates per treatment (three in our trial). Mortality was assessed on a daily basis throughout the experiment. All dead lepidopterans were counted and removed. Overall conditions during the bioassay period were very good. Temperature averaged $25^{\circ} \mathrm{C}$ (from $20^{\circ} \mathrm{C}$ at night to $27^{\circ} \mathrm{C}$ in the daytime) with almost no rain and a lot of sunshine. The plants inside the cages were connected to a drip irrigation system, so that watering of the plants occurred with minimal lepidopteran disturbance.

Mortality effects were analyzed by comparing the number of dead lepidopterans found in the different treatment groups. As illustrated by the data presented in Table 2, differences among treatment groups were observed immediately after the exposure was initiated. Mortality levels in the toxic reference cages remained high and statistically significant throughout the trial period.

The results obtained in corn semi-field and soybean field tests with formulations containing acetogenins were promising to control lepidopteran pests. Given the problems of environmental pollution by the use of highly toxic synthetic chemicals, it is necessary to find new ecologically friendly alternatives for insect control. Treatment with $R$. occidentalis acetogenin fraction is environmentally selective and shows an excellent degree of selectivity towards beneficial insects minimizing the detrimental effects of pesticides on natural enemies, allowing their survival and sustainable control of pests.

\section{Acknowledgements}

This work was supported by grants from the Agencia Nacional de Promoción Científica y Tecnológica (ANPCyT), Consejo de Investigaciones de la Universidad Nacional de Tucumán (CIUNT) and Concejo Nacional de Investigaciones Científicas y Técnicas (CONICET), República Argentina. Assays were carried out at Eugenio Sal’s field on Route 323, Tucumán, Argentina. Authors are especially grateful to him.

\section{References}

[1] Alkofahi, A., Rupprecht, J.K., Anderson, J.E., McLaughlin, J.L., Mikolajczak, K. and Scout, B. (1989) Search for New Pesticides from Higher Plants. In: Arnason, J.T., Philogene, B. and Morand, A., Eds., Insecticides of Plant Origin, ACS, Washington DC, 25-43. http://dx.doi.org/10.1021/bk-1989-0387.ch003

[2] Alali, F., Liu, X. and Mc Laughlin, J.L. (1999) Annonaceous Acetogenins: Recent Progress. Journal of Natural 
Products, 62, 504-540. http://dx.doi.org/10.1021/np980406d

[3] Guadaño, A., Gutiérrez, C., de La Peña, E., Cortes, D. and González-Coloma, A. (2000) Insecticidal and Mutagenic Evaluation of Two Annonaceous Acetogenins. Journal of Natural Products, 63, 773-776. http://dx.doi.org/10.1021/np990328+

[4] Hincapié Llanos, C.A., Lopera Arango, D. and Ceballos Giraldo, M. (2008) Insecticidal Activity of Annona muricata (Annonaceae) Seed Extracts on Sitophilus zeamais (Coleoptera: Curculionidae). Revista Colombiana de Entomología, 34, 76-82.

[5] Álvarez Colom, O., Neske, A., Popich, S. and Bardón, A. (2007) Toxic Effects of Annonaceous Acetogenins from Annona cherimolia (Magnoliales: Annonaceae) on Spodoptera frugiperda (Lepidoptera: Noctuidae). Journal of Pest Science, 80, 63-67. http://dx.doi.org/10.1007/s10340-006-0149-2

[6] Álvarez Colom, O., Barrachina, I., Ayala Mingol, I., González Mas, M.C., Moya Sanz, P., Neske, A. and Bardón, A. (2008) Toxic Effects of Annonaceous Acetogenins on Oncopeltus fasciatus. Journal of Pest Science, 81, 85-89. http://dx.doi.org/10.1007/s10340-007-0189-2

[7] Álvarez Colom, O., Salvatore, A., Willink, E., Ordóñez, R., Isla, M.I., Neske, A. and Bardón, A. (2010) Insecticidal, Mutagenic and Genotoxic Evaluation of Annonaceous Acetogenins. Natural Product Communications, 5, 391-394.

[8] Di Toto Blessing, L., Álvarez Colom, O., Popich, S., Neske, A. and Bardón, A. (2010) Antifeedant and Toxic Effects of Acetogenins from Annona montana on Spodoptera frugiperda. Journal of Pest Science, 83, 307-310. http://dx.doi.org/10.1007/s10340-010-0299-0

[9] Marenco, R.J., Foster, R.E. and Sanchez, C.A. (1992) Sweet Corn Response to Fall Armyworm (Lepidoptera: Noctuidae) Damage during Vegetative Growth. Journal of Economic Entomology, 85, 1285-1292.

[10] Kumar, H. and Mihn, J.A. (2002) Fall Armyworm (Lepidoptera: Noctuidae), Southwestern Corn Borer (Lepidoptera: Pyralidae) and Sugarcane Borer (Lepidoptera: Pyralidae) Damage and Grain Yield of Four Maize Hybrids in Relation to Four Tillage Systems. Crop Protection, 21, 121-128. http://dx.doi.org/10.1016/S0261-2194(01)00071-0

[11] Clavijo, S. and Pérez Greiner, G. (2000) Protección y sanidad vegetal (capítulo 6), Insectos plagas del maíz (sección 2). In: Fontana Nieves, H. and González Narváez, C., Eds., Fundación Polar, Caracas, 345-361.

[12] Murillo, A. (1991) Distribución, importancia y manejo del complejo Spodoptera en Colombia. Memorias Seminario Spodoptera frugiperda (El gusano cogollero) en sorgo, maíz y otros cultivos. In: Zuluaga, J.L. and Muñoz, G., Eds., Calí, Colombia, 15-23.

[13] Sparks, A.N. (1979) A Review of the Biology of the Fall Armyworm. Florida Entomologist, 62, 82-87. http://dx.doi.org/10.2307/3494083

[14] Murúa, M.G., Virla, E.G. and Defagó, V. (2003) Evaluación de cuatro dietas artificiales para la cría de Spodoptera frugiperda (Lep.: Noctuidae) destinada a mantener poblaciones experimentales de himenópteros parasitoides. Boletín de Sanidad Vegetal de Plagas, 29, 43-51.

[15] Murúa, M.G. and Virla, E. (2004) Population Parameters of Spodoptera frugiperda (Smith) (Lep.: Noctuidae) Fed on Corn and Two Predominant Grasess in Tucumán (Argentina). Acta Zoológica Mexicana, 20, 199-210.

[16] Tolosa, D., Álvarez Colom, O., Bardón, A. and Neske, A. (2012) Insecticidal Effects of Annonaceous Acetogenins from Rollinia occidentalis Seeds Extract on Spodoptera frugiperda. Natural Product Communications, 7, 1645-1646.

[17] Kawasu, K., Alcántara, J. and Kobayashi, A. (1989) Isolation and Structure of Neoannonin, a Novel Insecticidal Compound from the Seeds of Annona squamosa. Agricultural and Biological Chemistry, 53, 2719-2722. http://dx.doi.org/10.1271/bbb1961.53.2719 
Scientific Research Publishing (SCIRP) is one of the largest Open Access journal publishers. It is currently publishing more than 200 open access, online, peer-reviewed journals covering a wide range of academic disciplines. SCIRP serves the worldwide academic communities and contributes to the progress and application of science with its publication.

Other selected journals from SCIRP are listed as below. Submit your manuscript to us via either submit@scirp.org or Online Submission Portal.
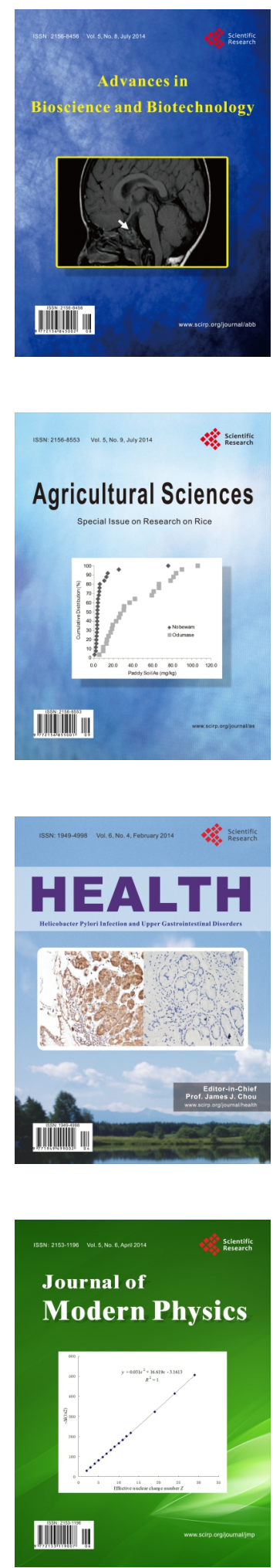
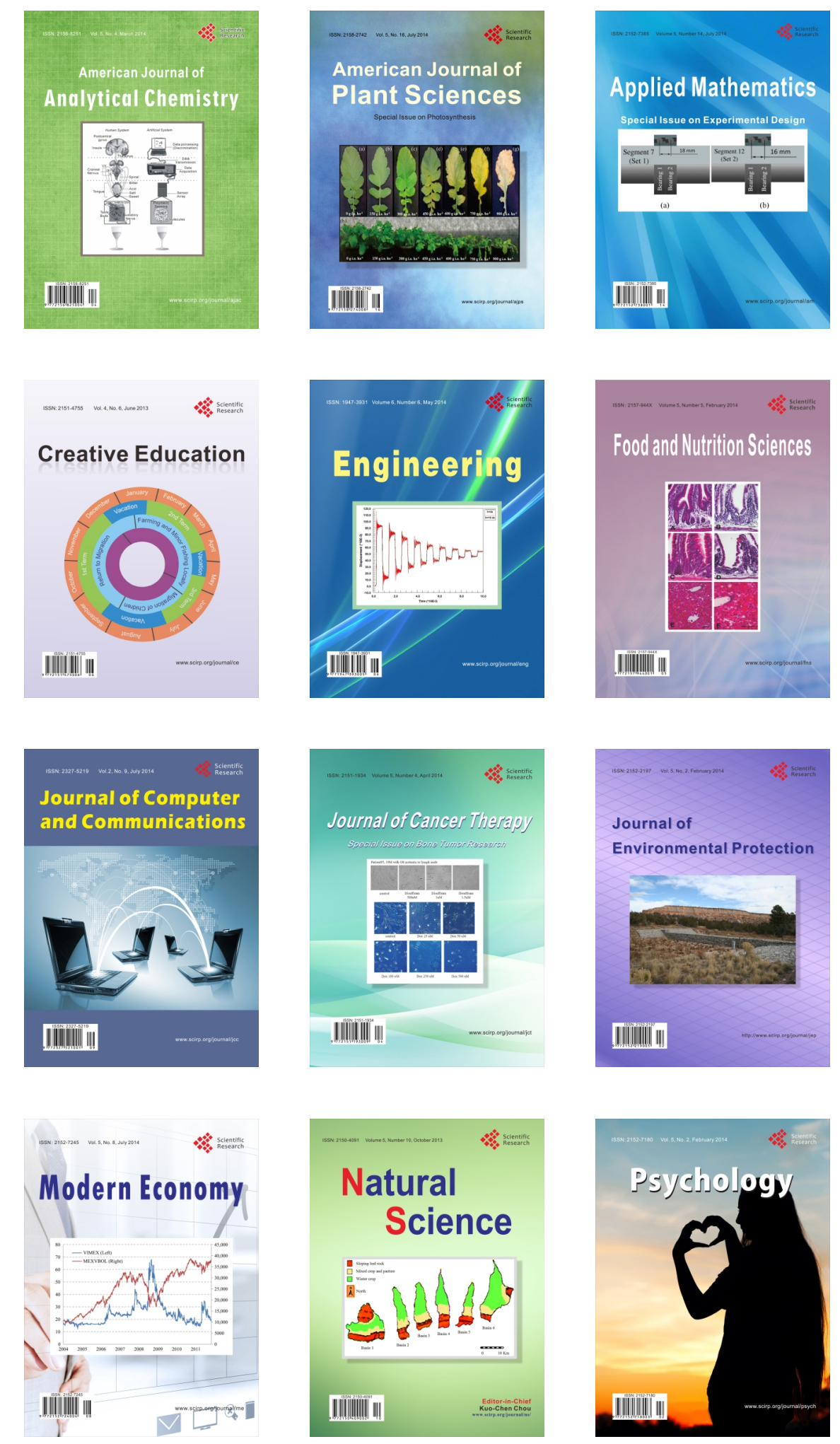